\title{
Antiproliferative Effect of Lignosus rhinocerotis, the Tiger Milk Mushroom on HCT 116 Human Colorectal Cancer Cells
}

\author{
C.F. Suziana Zaila ${ }^{1,2, *}$, M.Y. Farida Zuraina ${ }^{1}$, M.N. Norfazlina ${ }^{1,2}$, L. Lek Mun², N. Nurshahirah ${ }^{1,2}$, L. \\ Florinsiah $^{1,2}$ and N.F. Rajab ${ }^{2}$
}

${ }^{I}$ Faculty of Applied Sciences, Universiti Teknologi MARA, 40450 Shah Alam, Selangor, Malaysia; ${ }^{2}$ Biomedical Science Programme, Faculty of Health Sciences, Universiti Kebangsaan Malaysia, Jalan Raja Muda Abdul Aziz, 50300, Kuala Lumpur, Wilayah Persekutuan, Malaysia

\begin{abstract}
Tiger Milk mushroom is a unique mushroom that has number of medicinal properties. Communities in Malaysia have been using this mushroom to treat different kinds of cancer. This study was conducted to elucidate the antiproliferation activity of this national treasure mushroom on human colorectal cancer cells (HCT 116). Colon cancer cells were cultured in the presence of L. rhinocerotis for aqueous or methanol pressurized liquid extraction (PLE) at various concentrations for 24 hours. The percentage of cell viability was determined by 3-(4, 5-dimethylthiazol-2-yl)-2, 5di phenyl tetrazolium bromide (MTT) assay. Our results showed that methanol PLE of Lignosus rhinocerotis sclerotia was found to exhibit antiproliferative activity against HCT 116 cells, with an $\mathrm{IC}_{50}$ of $600 \mu \mathrm{g} / \mathrm{mL}$ and $1200 \mu \mathrm{g} / \mathrm{mL}$ for aqueous PLE. In comparison, both extractions did not show significant cytotoxicity against normal human colon cell (CCD$18 \mathrm{CO})$. The $\mathrm{IC}_{50}$ values suggested that the solvent differences in pressurized liquid extraction greatly affected their antiproliferative activites. Additionally, weak antioxidant capacities were detected in both methanol and aqueous PLE of L. rhinocerotis by the FRAP (Ferric Reducing Antioxidant Power) Assay. However, this capacity was not significant when the aqueous extract was tested in the presence of HCT 116 cells. Preliminary phytochemical screening revealed that both methanol and aqueous pressurized liquid extraction of $L$. rhinocerotis contained alkaloids.
\end{abstract}

Keywords: Human Colorectal Cancer Cells, Pressurized liquid extraction, MTT, Antiproliferation activity, Ferric reducing ability of plasma.

\section{INTRODUCTION}

CANCERS of the digestive system can be potentially life-threatening. In Malaysia, colorectal cancer (cancer of the colon and rectum) makes up more than $12 \%$ of the total number of recorded cancers in Malaysia [1]. Although surgical resection is curative in early stage disease, currently used chemotherapies for advanced colon cancer are mainly palliative [2]. Drug toxicity and the development of resistance to chemotherapeutic agents are also potential obstacles to the successful treatment of malignancies. More effective cancer-preventive and chemotherapeutic strategies for the management of colon cancer are therefore required. One promising approach involves the administration of dietary phytochemicals that possess cancer-preventative activity and growth inhibitory activity against cancer cells.

Tiger's milk fungus, is a novel mushroom with sclerotium belonging to the Polyporaceae family and has miraculous medicinal properties. Burkill (1966) documented that local communities use fungi for the treatment of a variety of ailments. He is also noted that the sclerotium of a Lignosus species ("cendawan susu harimau" or "susu rimau" in Malay language or tiger's milk fungus in English) was

*Address correspondence to this author at the School of Biological Sciences, Universiti Teknologi MARA, 40450 Shah Alam, Selangor, Malaysia; E-mail: Littlexiaochia@gmail.com used to treat consumption and coughs and this mushroom species are still used by the Malays, Chinese and indigenous communities in Malaysia [3]. For many years ago, it is used by indigenous communities as a general tonic, to treat cancer and swollen breast as well as medicinal treatments for food poisoning. Furthermore, the local malay communities have been using tiger milk mushroom to treat different kinds of cancer including stomach and breast cancer and as medication for swellings all over the body [4]. Previous studies have shown that the sclerotium of $L$. rhinocerotis is a traditional Chinese medicine in which there has been some preliminary data showing their effectiveness in treating liver cancer, chronic hepatitis and gastric ulcer [5].

Antioxidant agents are closely associated to the prevention of degenerative diseases, such as cardiovascular and neurological illnesses, oxidative stress malfunctions and cancer [6]. In this paper, the Ferric Reducing Ability of Plasma (FRAP) activity of some L. rhinocerotis, has been evaluated. This assay is simple and comparatively cheap. It utilizes the reducing potential of the antioxidants to react with a ferric tripyridyltriazine (FeIII-TPTZ) complex and produce a colored ferrous tripyridyltriazine (FeII-TPTZ) [7].

\section{MATERIALS AND METHODS}

\subsection{Lignosus rhinocerotis}

L. rhinocerotis (Tiger Milk mushroom) were collected from indigenous people in Sg. Perak. The sequence of pre- 
treatment for Tiger Milk mushroom extract include: Peeling the sclerotia, slicing, followed by drying and grinding prior to solvent extraction.

\subsection{Pressurized Liquid Extraction}

PLE was performed on a Dionex ASE 150 system (Dionex Corp., Sunnyvale, CA, USA) in two solvent under optimized conditions. Dried powder of Lignosus rhinocerotis sclerotium $(\sim 15 \mathrm{~g})$ was placed into an $66 \mathrm{~mL}$ stainless steel extraction cell, then extracted with two different solvent $70 \%$ aqueous methanol and aqueous at $100{ }^{\circ} \mathrm{C}$ for $15 \mathrm{~min}$ of static time for 1 cycle with pressure at $1.034 \times 104 \mathrm{kPa}$. The extract purged out by nitrogen was transferred into a $25 \mathrm{~mL}$ volumetric flask, which was made up to its volume with the same solvent. The extract will be completely lyophilized by continuous freeze drying operation for 72 hours, yielding a certain amount of crude extract. A dark semi-solid material will be stored at $4^{\circ} \mathrm{C}$ to be used later.

\subsection{Cell Lines and Cell Culture Condition}

The human colorectal cancer (HCT 116 ) and normal human colon cell (CCD-18CO) cell lines were obtained from American Type Culture Collection (ATCC), Maryland, USA. HCT 116 cells were maintained in McCoy's 5A Medium (modified) (1X), and CCD-18CO cells were maintained in Eagle's minimal essential medium (EMEM), McCoy's 5A Medium supplemented with 10\% fetal bovine serum (FBS) and 1\% Penicillin Streptomycin while $2 \mathrm{mM}$ glutamine and 1\% Non-Essential Amino Acids 10\% FBS in EMEM. Both type of cells were maintained in $75 \mathrm{~cm}^{2}$ flask at $37^{\circ} \mathrm{C}$ in a humidified atmosphere with $5 \% \mathrm{CO}_{2}$.

2.4. Cell Viability Assay: 3-(4,5-dimethylthiazol-2-yl)2,5- diphenyl Tetrazolium Bromide (MTT) Assay

For cell viability assay, $5 \times 10^{4}$ cells (HCT 116 and V794) per well were plated in $100 \mu$ of McCoy's and DMEM media each. HCT 116 and CCD-18CO cells were incubated overnight at $37^{\circ} \mathrm{C}$ in humidified atmosphere of $5 \% \mathrm{CO} 2$ for cells attachment. Tiger milk mushroom extract was added at various concentrations ranging from $0,125,250,500,1000$, and $2000 \mu \mathrm{g} / \mathrm{mL}$ after $24 \mathrm{~h}$ incubation. After $24 \mathrm{~h}$ incubation, MTT solution $(2 \mathrm{mg} / \mathrm{mL}$ ) was added to the plate at the final concentration of $0.5 \mathrm{mg} / \mathrm{mL}$. The resulting MTT- products were determined by measuring the absorbance at $570 \mathrm{~nm}$ with ELISA reader. Each point represents the mean of triplicate experiments.

$$
\% \text { viability }=\frac{\text { Optical density of sample }}{\text { Optical density of control }} \times 100
$$

\subsection{Ferric Reducing/Antioxidant Power (FRAP) Assay}

Briefly, the FRAP reagent was prepared by mixing acetate buffer (300 1M, pH 3.6), a solution of $101 \mathrm{M}$ TPTZ in $40 \mathrm{lM} \mathrm{HCl}$, and $20 \mathrm{lM} \mathrm{FeCl} 3$ at 10:1:1 (v/v/v). The reagent $(175 \mu \mathrm{l})$ and sample solutions $(50 \mu \mathrm{l})$ were added to each well and mixed thoroughly. The absorbance was taken at 593 $\mathrm{nm}$ after $5 \mathrm{~min}$. Standard curve was prepared using different concentrations of ascorbic. All solutions were used on the day of preparation. The results were corrected for dilution (e.g. to $1000 \mathrm{~mL}$ ). The reducing ability of biological sample was determined by FRAP assay of Benzie and Strain (1996). FRAP assay was based on the reducing power of a compound that has antioxidant properties. A potential antioxidant will reduce the ferric ion $\left(\mathrm{Fe}^{\mathrm{III}}\right)$ to the ferrous ion $\left(\mathrm{Fe}^{\mathrm{II}}\right)$ resulting a blue coloured $\mathrm{Fe}^{\mathrm{II}}$-tripyridyltriazine compound and the absorbance values were measured at 595 $\mathrm{nm}$. The oxidised $\mathrm{Fe}^{\mathrm{III}}$ color form by the action of electron donating antioxidants.

\subsection{Phytochemical Screening}

Phytochemical screening was performed on the extracts using standard procedures to identify chemical constituents as described by Trease and Evans (1989), Harborne (1973) and Sofowora (1993) [8-10].

\section{Screening for Alkaloid}

$0.5 \mathrm{~g}$ of the extract was stirred in $5 \mathrm{ml}$ of $1 \% \mathrm{HCl}$ on a steam bath and filtered while hot. Distilled water was added to the residue and $1 \mathrm{ml}$ of the filtrate was treated with a few drops of Wagner's reagent. A reddish brown precipitate indicates the presence of alkaloids.

\section{Screening for Flavonoids}

Two millilitres of dilute sodium hydroxide was added to $2 \mathrm{ml}$ of the extract. The appearance of a yellow color indicates the presence of flavonoids.

\section{Screening for Saponins}

One milliliter of distilled water was added to $1 \mathrm{ml}$ of the extract and shaken vigorously. A stable persistent froth indicated the presence of saponins.

\section{Screening for Phenols}

Equal volumes $(1 \mathrm{ml})$ of extract and Iron (III) chloride were mixed. A deep bluish green solution gave an indication of the presence of phenols.

\section{Screening for Tannins}

A portion of the extract was dissolved in water, after which the solution was clarified by filtration. $10 \%$ ferric chloride solution was then added to the resulting filtrate. The appearance of a bluish black colour indicates the presence of tannins.

\section{Screening for Anthraquinones}

$0.5 \mathrm{~g}$ of the extract was shaken with $10 \mathrm{ml}$ of benzene and filtered. $10 \%$ of ammonia solution was added to filtrate and the mixture was shaken. The formation of a pink, red or violet color on the ammoniacal phase indicates the presence of anthraquinones.

\section{Screening for Terpenoids}

$0.5 \mathrm{ml}$ of acetic anhydride was mixed with $1 \mathrm{ml}$ of sample extract and a few drops of concentrated $\mathrm{H}_{2} \mathrm{SO}_{4}$. A bluish green precipitate indicates the presence of terpenes.

\section{RESULT}

3.1. Cell Viability Assay: 3-(4,5-Dimethylthiazol-2-yl)-2,5diphenyl Tetrazolium Bromide (MTT) Assay

To determine optimal conditions for cytotoxicity in cultures of HCT-116 colon cancer cells, cell viability at 24 hours was then assessed by MTT assay. The HCT-116 human colon cancer cells were treated with various 


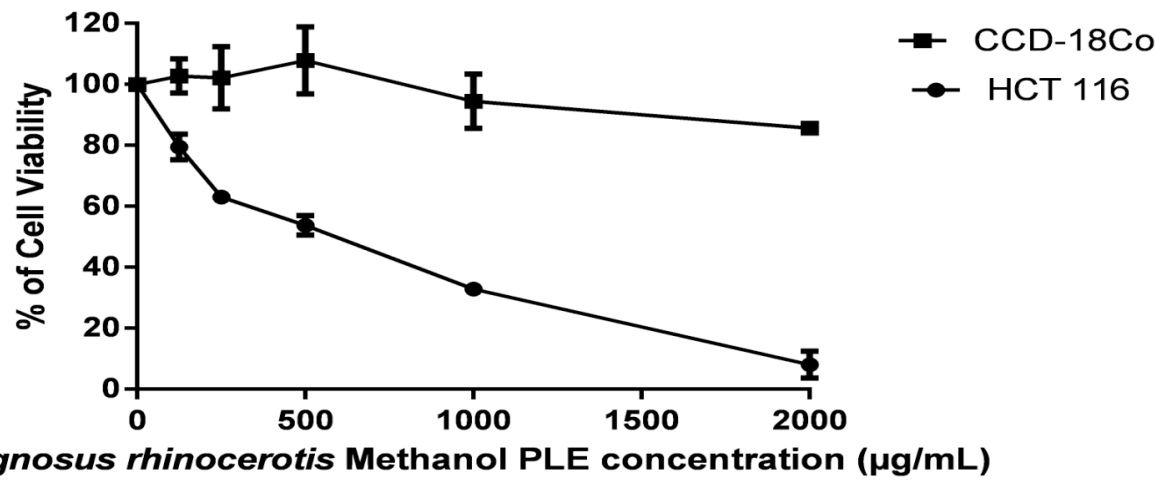

Fig. (1). Effect of Tiger Milk mushroom extract on the proliferation of HCT 116 \& CCD-18Co cells. Cells were treated with different concentration of methanol PLE Tiger Milk mushroom PLE, incubated at $37^{\circ} \mathrm{C}$ and harvested after 24 hour. Cell viability was determined by the MTT assay. Data represent the mean \pm S.E.M $(n=3)$.

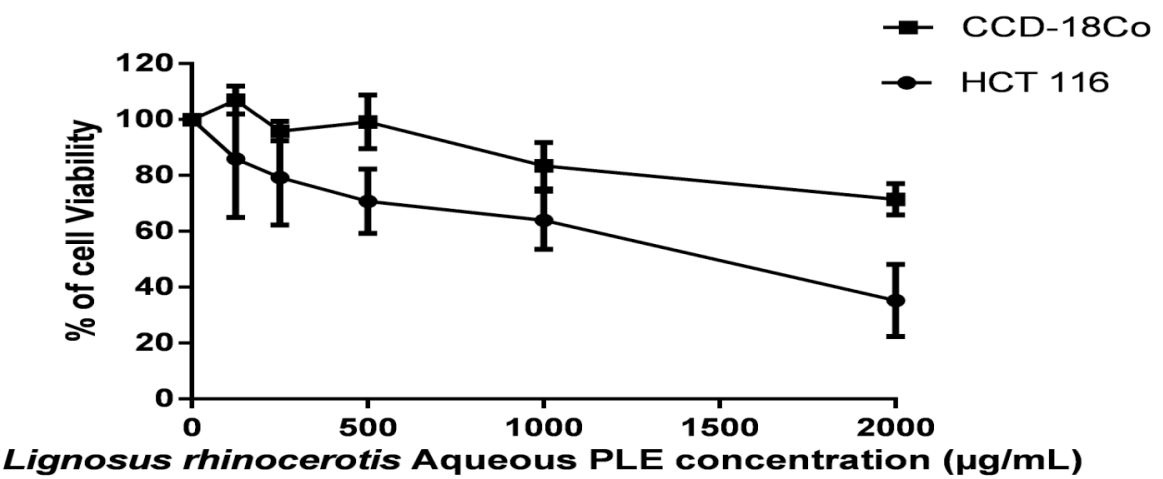

Fig. (2). Effect of Tiger Milk mushroom PLE on the proliferation of HCT 116 \& CCD-18Co cells. Cells were treated with different concentration of aqueous PLE Tiger Milk mushroom PLE, incubated at $37^{\circ} \mathrm{C}$ and harvested after 24 hour. Cell viability was determined by the MTT assay. Data represent the mean \pm S.E.M $(n=3)$.

concentrations of tiger milk mushroom PLE at different concentrations in $10 \%$ FBS.

Table 1. Cytotoxic Activities $\left(\mathrm{IC}_{50}\right)$ of Methanol Pressurized Liquid Extraction of Sclerotia of Tiger Milk Mushroom and Aqueous Pressurized Liquid Extraction. Treatment time was 24 Hours

\begin{tabular}{|c|c|c|}
\hline Extracts & HCT $116(\mu \mathrm{g} / \mathrm{mL})$ & $\operatorname{CCD}-18 C o(\mu \mathrm{g} / \mathrm{mL})$ \\
\hline $\begin{array}{l}\text { Methanol pressurized } \\
\text { liquid extraction }\end{array}$ & $600 \pm 0.09$ & ND \\
\hline $\begin{array}{l}\text { Aqueous pressurized } \\
\text { liquid extraction }\end{array}$ & $1200 \pm 0.05$ & ND \\
\hline
\end{tabular}

$\mathrm{ND}=$ Not Determine

Table 2. Percentage Increase of FRAP Values of Methanol PLE. Each Value Represents the mean \pm S.E.M. of Triplicate from 3 Different Experiment

\begin{tabular}{|c|c|}
\hline $\begin{array}{c}\text { Tiger Milk Mushroom ple } \\
\text { (Methanol) }(\boldsymbol{\mu g} / \mathbf{m L})\end{array}$ & $\begin{array}{c}\text { Percentage Increase in Frap } \\
\text { Value mean } \pm \mathbf{s e m}\end{array}$ \\
\hline \hline 0 & $0 \pm 0$ \\
\hline \hline 125 & $6.95 \pm 1.04$ \\
\hline 250 & $9.33 \pm 1.78$ \\
\hline 500 & $28.31 \pm 3.82$ \\
\hline
\end{tabular}

\begin{tabular}{|l|l|}
\hline 1000 & $41.34 \pm 4.98$ \\
\hline 2000 & $76.59 \pm 2.55$ \\
\hline
\end{tabular}

Table 3. Percentage Increase of frap Values of Aqueous PLE. Each value Represents the mean \pm s.e.m. of Triplicate from 3 Different Experiment

\begin{tabular}{|c|c|}
\hline $\begin{array}{c}\text { Tiger Milk Mushroom ple } \\
\text { (Aqueous)( } \boldsymbol{\mu g} / \mathbf{m L})\end{array}$ & $\begin{array}{c}\text { Percentage Increase in Frap } \\
\text { value mean } \pm \mathbf{s e m}\end{array}$ \\
\hline \hline 0 & $0 \pm 0$ \\
\hline 125 & $4.55 \pm 1.83$ \\
\hline 250 & $4.40 \pm 2.63$ \\
\hline 500 & $12.87 \pm 4.99$ \\
\hline 1000 & $25.48 \pm 8.34$ \\
\hline 2000 & $48.91 \pm 7.08$ \\
\hline
\end{tabular}

\section{DISCUSSION}

We have selected L. rhinocerotis in this study is to investigated the effects of Lignosus rhinocerotis sclerotium extracted by using PLE method on HCT 116 cell lines. Our results indicated that both aqueous and methanol PLE exhibit significant antiproliferative activity against human colorectal cancer cells HCT 116. The antiproliferative active against HCT 116 provides a basis for asserting scientific plausibility for traditional use of $L$. rhinocerotis in colon cancer treatment by Malaysian natives. Proliferation of HCT 116 


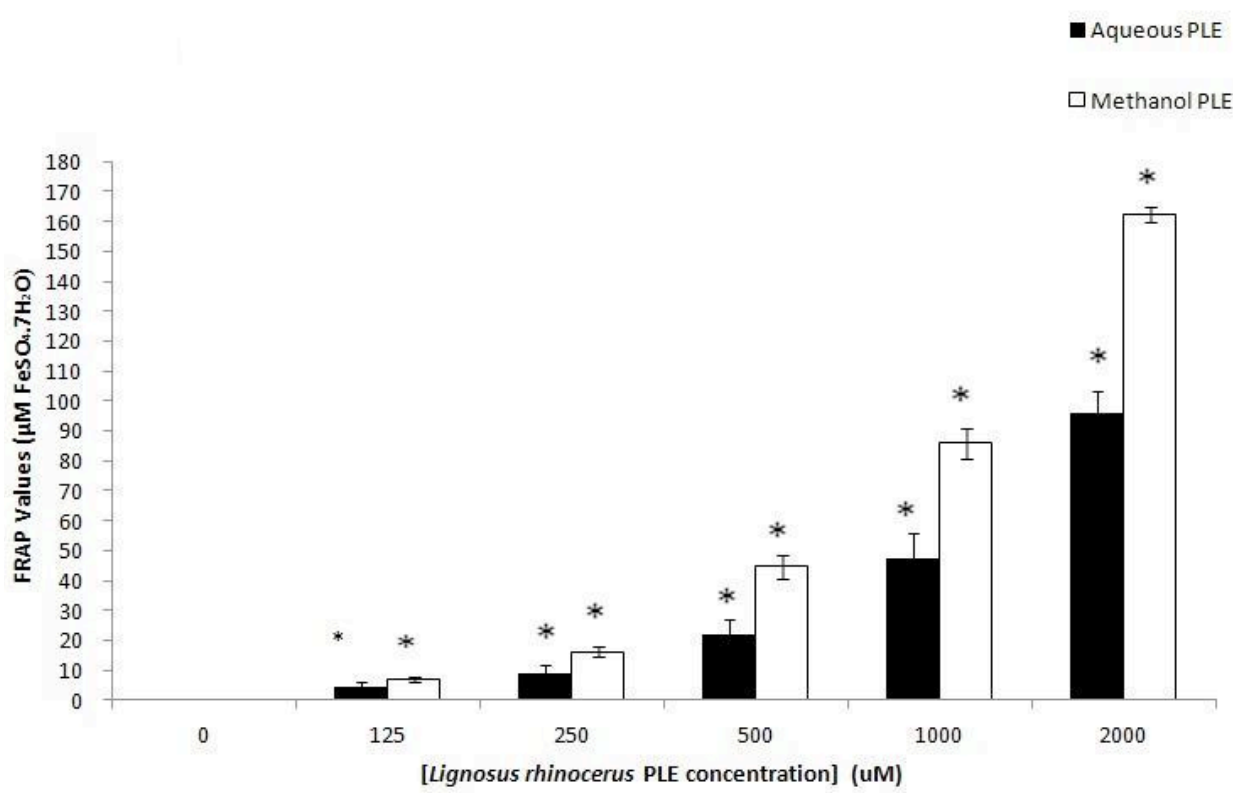

Fig. (3). FRAP values (Total Antioxidant Content) versus concentration of aqueous and methanol PLE graph. Note: * indicated significant differences $(\mathrm{p}<0.05)$ between control and treatment groups. Data was expressed as mean $\pm \operatorname{SEM}(n=3)$.

cells decreased when treated with L. rhinocerotis methanol PLE extract resulting in a $50 \%$ reduction at $600 \pm 0.09$ $\mu \mathrm{g} / \mathrm{mL}$, while for aqueous PLE extract showed significant decrease in proliferation of HCT 116 cells with $50 \%$ reduction at $1200 \pm 0.05 \mu \mathrm{g} / \mathrm{mL}$ of L. rhinocerotis extract (Table 1), suggesting that methanol PLE $\mathrm{IC}_{50}$ much more lower than aqueous PLE because many organic molecules are soluble in methanol. The presence of water in aqueous methanol $(70: 30 \mathrm{v} / \mathrm{v})$ will almost certainly allow water soluble material in the mushroom to be extracted more readily that caused the $\mathrm{IC}_{50}$ value of methanol PLE lower than aqueous PLE. Statistical analysis indicated that both methanol and aqueous PLE possess significant $(* p<0.05)$ reduction in total cell numbers. Our results demonstrated that antiproliferative activity by $L$. rhinocerotis sclerotia was found to exhibit against HCT 116 cells were included in Fig. (1 and 2). The $\mathrm{IC}_{50}$ values suggested that the solvent differences in pressurized liquid extraction greatly affected their antiproliferative activites. Besides, Lignosus rhinocerotis powder was extracted using Accelerated Solvent Extraction (ASE 150) machine which is a single-cell system for the extraction of solid and semisolid samples at elevated

Table 4. Phytochemical Analysis of Presurrized Liquid Extraction of Tiger Milk Mushroom

\begin{tabular}{|c|c|c|}
\hline Phytochemical & Methanol PLE & Aqueous PLE \\
\hline \hline Alkaloids & ++++ & ++++ \\
\hline Triterpenoid/ Steroid & - & - \\
\hline Saponin & - & - \\
\hline Phenols & - & - \\
\hline Anthraquinones & - & - \\
\hline Tannins & - & - \\
\hline Flavonoids & - & - \\
\hline
\end{tabular}

$+=$ present, $-=$ absent, ++++ highly present temperatures and pressures that runs faster than Soxhlet, sonication, and other extraction methods, besides requires less solvent and labor. PLE is also a rapid and effective method for sample preparation of carbohydrates $[11,12]$.

A recent study of mushroom sclerotium had indicated that various fractions of sclerotial polysaccharides including water-soluble polysaccharide-protein complex (PSP) and alkali-soluble b-glucan isolated from $L$. rhinocerotis possessed remarkable host-mediated antitumor activity on the Sarcoma 180 implanted BALB/c mice. Besides, polysaccharides isolated from the fruit bodies and mycelia of L. rhinocerotis have been found to exert immunomodulatory function and antitumor activity in numerous in vivo and in vitro studies [13]. The antiproliferative agent may either be a type of protein-carbohydrate complex and proteins that target metabolic processes or signal transduction in cancer cells [14].

Although there has been no research about the anti-tumor effects of L. rhinocerotis on the HCT-116 cell line, some research has already demonstrated the inhibitory effects of $L$. rhinocerotis on cancer cells. In the previous study shown that $L$. rhinocerotis inhibits both breast and lung cancer cell proliferation in a concentration-dependent and timedependent manner both in 24 hour [15]. Extensive investigation over the past few years has confirmed that Tiger Milk mushroom has an anticarcinogenic and cancerkilling activity. A few articles also demonstrated the significant growth inhibition of $L$. rhinocerotis on various human leukemic cell lines including HL-60, K562 and THP1. It is also revealed that the onset of apoptosis of the HL-60 cells by the cell cycle arrest at G1 phase using flow cytometric analysis [16]. Additionally, a recent study also discovered that L. rhinocerotis has an effective antimicrobial activity against the selected pathogenic bacteria and fungi which are responsible for wound [17].

The therapeutic value of any drugs depends not only on its clinical efficacy, but also in its lack of toxic side-effects 
[18]. A successful anticancer drug should kill or incapacitate cancer cells without causing excessive damages to normal cells. In this investigation, MTT assay showed that the $L$. rhinocerotis methanol and aqueous PLE did not toxic to normal human colon cell CCD-18CO. In addition, previous studies have shown that there was no treatment-related subacute toxicity in rats following 28 days at the highest tested dose of $1,000 \mathrm{mg} / \mathrm{kg}$ of wild type Lignosus rhinocerotis sclerotial powder [19]. Earlier, Lee et al. also reported that cold water extraction of $L$. rhinocerotis did not show significant cytotoxicity against human normal cells, 184B5 (human breast cell) and NL 20 (human lung cell) [20]. These results indicate that the extracts are relatively safe to use for therapeutic purpose.

Whereas for the FRAP assay, the higher the concentration of $L$. rhinocerotis PLE extraction, the ability to reduce the ferric ion $\left(\mathrm{Fe}^{\mathrm{III}}\right)$ to the ferrous ion $\left(\mathrm{Fe}^{\mathrm{II}}\right)$ were increased (Table 2 and 3). The FRAP values of aqueous PLE were, however, much lower than the values for methanol PLE, suggested that the solvent differences in pressurized liquid extraction greatly affected their total FRAP values. The value of methanol/water $(70: 30 \mathrm{v} / \mathrm{v})$, which was much higher than aqueous PLE demonstrated the influence of the solvent, as previously reported [21]. From statistical analysis, our results indicated that there is a significant different in the means of concentration among different concentration level. Also, there is a significant different in the means of concentration between different type of solvent that is aqueous and methanol (Fig. 3). However, the ferric reducing antioxidant power (FRAP) method is based on the reduction of a ferroin analogue, the $\mathrm{Fe} 3+$ complex of tripyridyltriazine $\mathrm{Fe}(\mathrm{TPTZ}) 3+$ to the intensely blue-coloured Fe2+ complex Fe(TPTZ)2+ by antioxidants in acidic medium. However, the reducing capacity does not necessarily reflect antioxidant activity $[22,23]$. FRAP values of both methanol and aqueous PLEs was significant as compared to the negative control but this value was low than L-ascorbic acid at the same concentration. This showed that Lignosus rhinocerotis PLEs had weak antioxidant capacities.

Preliminary phytochemical screening revealed that both methanol and aqueous pressurized liquid extraction of $L$. rhinocerotis contained alkaloids (Table 4). The highly trace of alkaloid might be responsible for the anticancer activity. The earlier studies stated that several alkaloids isolated from natural herbs exhibit antiproliferation and antimetastasis effects on various types of cancers both in vitro and in vivo [24]. One of the most common biological properties of alkaloids is their toxicity against cells of foreign organisms. These activities have been widely studied for their potential use in the elimination and reduction of human cancer cell lines [25]. Alkaloids which are one of the largest groups of phytochemicals in plants have amazing effects on humans and this has led to the development of powerful pain killer medications [26].

\section{STATISTICAL ANALYSIS}

Each experiment were repeated at least 3 times and the results were expressed as mean \pm S.E.M. The significance of difference between the experimental group and control was assessed by Student's $t$ test. For the Frap assay the difference is considered significant if the $p$ value is $<0.05$.

\section{CONCLUSION}

The above data suggested that pressurized liquid extraction (PLE) extract of the sclerotia of L. rhinocerotis possesses cytotoxicity to human colorectal cancer cells but were non-toxic to the corresponding normal cells. Here, we only presented the therapeutic results. Therefore, further study is suggested to investigate the mode of action and the mechanism of antitumor effects of tiger milk mushroom extract by evaluating apoptosis rate and cell cycle progression status in colon cancer cell lines HCT 116.

\section{CONFLICT OF INTERESTS}

To our knowledge, previous studies have shown the antitumor effect of L. rhinocerotis in other cancer cells but no report evidence on colon cancer cells. Thus, our study represent among the first to show the antiproli ferative effect of L. rhinocerotis in colon cancer cells HCT 116.

\section{ACKNOWLEDGEMENTS}

The authors wish to thanks Universiti Teknologi MARA for providing research grant. Likewise, the authors are grateful with Universiti Kebangsaan Malaysia, KL for their kind cooperation and for granting permission to utilize their Biocompatibility \& Toxicology Laboratory, Faculty of Health Sciences, Universiti Kebangsaan Malaysia.

\section{REFERENCES}

[1] Gerard, L.C.C.; Halimah, Y. Second Report of the National Cancer Incidence in Malaysia National Cancer Registry. Malaysian Ministry of Health: Malaysia, 2007.

[2] Kawai, N.; Ito, A.; Nakahara, Y.; Futakuchi, M.; Shirai, T.; Honda, H.; Kobayashi, T.; Kohri, K. Anticancer effect of hyperthermia on prostate cancer mediated by magnetite cationic liposomes and immune-response induction in transplanted syngeneic rats. Prostate, 2005, 64, 373-381.

[3] Burkill, I.H. A Dictionary of the Economic Products of the Malay Peninsula, vol. I \& II. Ministry of Agriculture: Kuala Lumpur, 1966

[4] Tan, C.S.; Ng, S.T.; Vikineswary, S.; Lo, F.P.; Tee, C.S. Genetic markers for identification of a malaysian medicinal mushroom, Lignosus rhinocerus (cendawan susu rimau). In: Int. Mol. Markers. Horticult., 2009, pp. 24-26.

[5] Huang, N. L. Identification of the scientific name of Hurulingzhi Acta Edulis Fungi, 1999, 6, 30-32.

[6] Diplock, A. Antioxidant nutrients- efficacy in disease prevention safety. Biochemist, 1995, 17, 16-8.

[7] Benzie, I.F.F.; Strain, J.J. Ferric reducing ability of plasma (FRAP) measure of antioxidant power: The FRAP assay. Biochemistry, 1996, 239, 70 -76.

[8] Trease, G.E.; Evans W.C. Pharmacology. $11^{\text {th }}$ ed, Bailliere Tindall Ltd.: London, 1989, pp.60-75.

[9] Harborne, J.B. Photochemical Methods: A Guide to Modern Techniques of Plant Analysis. Chapman A. \& Hall: London, 1973, p. 279.

[10] Sofowora, A. Medicinal Plants and Traditional Medicines in Africa. Chichester John Wiley \& Sons: New York, 1993, pp. 97145.

[11] Sanz, M.L.; Martínez-Castro, I. Recent developments in sample preparation for chromatographic analysis of carbohydrates. $J$. Chromatogr. A, 2007, 1153, 7489 .

[12] Ruiz-Matute, A.I.; Ramos, L.; Martínez-Castro, I.; Sanz, M.L. Fractionation of honey carbohydrates using pressurized liquid extraction with activated charcoal. J. Agric. Food Chem., 2008, 56, 8309-8313.

[13] Wong, K.H.; Lai, C.K.M.; Peter, C.C.K. Immunomodulatory activities of mushroom sclerotial polysaccharides. Food Hydrocoll., 2010, 25(2), 150-158. 
[14] Lindequist, U., Miedermoyer, T.H.J.; Julich, W.D. The pharmacological potential of mushrooms. Evid. Based Complement Alternat. Med., 2005, 2(3), 285-299.

[15] Wong, K.H., Lai, K.M., Cheung, C.K. Immunomodulatory activities of mushroom sclerotial polysaccharides. Food Hydrocoll., 2011, 25(2), 150-158.

[16] Lai, C.K.M.; Wong, K.H.; Cheung, P.C.K. Antiproliferative effects sclerotial polyssacharides from Polyporus rhinoceros sclerotial polyssacharides from Polyporus rhinoceros Cooke (Aphyllophoromy cetideae) on different kinds of leukemic cells. Int. J. Med. Mushrooms, 2008, 10(3), 255-264.

[17] Mohanarji, S.; Dharmalingam, S.; Kalusalingam, A. Screening of Lignosus rhinocerus Extracts as Antimicrobial Agents against Selected Human Pathogens. Int. J. Biomed. Pharm. Sci., 2012, 18, 18.

[18] Aggarwal, B.B.; Kunnumakkara, A.B.; Harikumar, K.B.; Tharakan S.T.; Sung, B.; Anand, P. Potential of spice-derived phytochemicals for cancer prevention. Planta Med., 2008, 74(13). 1560-1569.

[19] Lee, S.S.; Tan, N.H.; Fung, S.Y.; Pailoor, J.; Sim, S.M. Evaluation of the sub-acute toxicity of the sclerotium of Lignosus rhinoceros, (Cooke), the Tiger Milk mushroom. J. Ethnopharmacol., 2011, $138,192-200$.
[20] Lee, E.; Surh, Y.J. Induction of apoptosis in HL-60 cells by pungent vanilloids, [6]-gingerol and [6]-paradol. Cancer Lett., 1998, 134, 163-168.

[21] Pulido, R.; Bravo, L.; Saura-Calixto, F. Antioxidant of dietary polyphenols as determined by a modified Ferric Reducing Power assay. J. Agric. Food. Chem., 2000, 46, 3396-3402.

[22] Wong, C.C.; Li, H.B.; Cheng, K.W.; Chen, F. A systematic survey of antioxidant activity of 30 Chinese medicinal plants using the ferric reducing antioxidant power assay. Food Chem., 2006, 97, 705-711.

[23] Katalinic, V.; Milos, M.; Jukic, M. Screening of 70 medicinal plant extracts for antioxidant capacity and total phenols. Food Chem., 2006, 94, 550-557.

[24] Lu, J.J.; Bao, J.L.; Chen, X.P.; Huang, M.; Wang Y.T. Alkaloids Isolated from Natural Herbs as the Anticancer, Agents. Evid. Based Complement Alternat. Med., 2012, 2012, 12.

[25] Nobori, T.; Miurak, K.; Wu, D.J.; Takabayashik, L.A.; Carson, D.A. Deletion of the cyclin-dependent kinase-4 inhibitor gene in multiple human cancers. Nature, 1994, 368(6473),753-756.

[26] Kam, P.C.A.; Liew. Traditional Chinese herbal medicine and anaesthesia. Anaesthesia, 2002, 57(11), 1083-1089.

(C) Zaila et al.; Licensee Bentham Open.

This is an open access article licensed under the terms of the Creative Commons Attribution Non-Commercial License (http://creativecommons.org/licenses/by$\mathrm{nc} / 3.0 /$ ), which permits unrestricted, non-commercial use, distribution and reproduction in any medium, provided the work is properly cited. 